\title{
NOTES
}

\section{DISCOVERY OF AN ATTORNEY'S WORK PRODUCT IN SUBSEQUENT LITIGATION}

Over the course of the past decade, the federal courts, in a series of cases, have been faced with the question of whether to allow discovery of inaterials prepared by an attorney in preparation for prior litigation. While these materials-denoted attorney's work product ${ }^{1}$ -are, under the doctrine of Hickman v. Taylor, ${ }^{2}$ protected from discovery in the case for which they are prepared, the courts have reached conflicting decisions as to whether such materials merit continued work product protection in later actions. This Note will discuss the rationale for affording any special protection to a lawyer's work product; examine, in the light of this rationale, the various approaches the courts have taken in dealing with discovery of work product in subsequent litigation; and propose a test for determining when a lawyer's work product from a prior case should be discoverable.

\section{The Development of Liberal Discovery}

Discovery is "the process by which a party obtains . . . information and other materials relevant to a pending lawsuit." 3 The purposes of discovery are to delineate clearly the issues in the case, to ensure that all relevant evidence will be made available to the trier of fact, and to encourage pretrial settlement of claims. ${ }^{4}$ Prior to 1938 , dis-

1. A brief definition of "work product" may be found in note 15 infra.

HEREAFTER THE FOLLOWING CITATIONS WILL BE USED IN THIS NOTE:

J. Moore, Moore's Federal Practice (2d ed. 1972) [hereinafter cited as Moore];

C. Wright \& A. Miller, Federal Practice and Procedure (1970) [hereinafter cited as WRIGHT \& MILLER];

Cooper, Work Product of the Rulesmakers, 53 MinN. L. REv. 1269 (1969) [hereinafter cited as Cooper];

Developments in the Law-Discovery, 74 HARv. L. REv. 940 (1961) [hereinafter cited as Developments].

2. 329 U.S. 495 (1947). See note 15 and notes $23-63$ infra and accompanying text.

3. Developments 942.

4. See id. at 944-46. Discovery enables parties to determine the issues on which they are in agreement and which issues are effectively out of the case (because of oue party's inability to ineet his burden of proof), thereby enabling each party to devote 
covery was severely limited in the federal courts. 5 In actions at law, depositions could be taken under certain circumstances in order to perpetuate testimony, but not for discovery purposes; ${ }^{6}$ in equity, depositions could be taken upon a showing of exceptional cause, ${ }^{7}$ as well as to perpetuate testimony, ${ }^{8}$ and written interrogatories were available by means of a cumbersome procedure known as a bill of discovery. ${ }^{0}$ At both law and equity, the federal provisions for discovery were generally inferior to those in the state courts. ${ }^{10}$

In 1938, however, law and equity were merged and discovery was liberalized when the Supreme Court adopted the Federal Rules of Civil Procedure. ${ }^{11}$ The new Federal Rules provided a number of

his efforts to the points of actual dispute. Furthermore, if each party knows the relative strengths and weaknesses of his opponent's case, he will be in a better position to evaluate rationally the merits of pretrial settlement.

5. See generally 4 MOORE II 26.03; Millar, The Mechanism of Fact-Discovery: A Study in Comparative Civil Procedure, 32 ILL. L. REv. 424, 437-52 (1937).

6. Two types of depositions were in use. A deposition de bene esse could be taken if the witness might be unavailable at trial for one of five different reasons. Judiciary Act of 1789, ch. 20, $\$ 30,1$ Stat. 88, as amended, Act of May 9, 1892, ch. 146, 17 Stat. 89.

A deposition could be taken under a dedimus potestatem when it was "necessary to prevent a failure or delay of justice." Judiciary Act of 1789, ch. 20, § 30, 1 Stat. 88. See 4 MOORE Tा 26.03[1].

The bill of discovery, see note 9 infra and accompanying text, was available as an action brought in equity for discovery iu aid of an action at law, but only in exceptional circumstances. See Pressed Steel Car Co. v. Union Pac. R.R., 240 F. 135 (S.D.N.Y. 1917); 4 MOORE II 26.02[1], at 26-80; 4A MOORE If 33.03[1].

7. Equity R. 47, 226 U.S. 661 (1912).

8. The deposition in perpetuam rei memoriam could be authorized in order to prevent a loss of testimony for purposes of a pending action. Judiciary Act of 1789, ch. 20, § 30, 1 Stat. 88. See 4 MOORE If 27.02 .

9. Equity R. 58, 226 U.S. 665 (1912).

10. Developments $\mathbf{9 5 0}$. The Conformity Act of $\mathbf{1 8 7 2}$ had provided that the federal courts should apply "as near as may be" the procedure governing actions at law in the states in which they were located. Act of June 1, 1872, ch. 255 , 5 , 17 Stat. 197. However, this provision was construed to mean that only the method of taking depositions could be borrowed from the state courts, implying that the devices for "discovery" provided under federal law were exclusive. Hanks Dental Ass'n v. International Tooth Crown Co., 194 U.S. 303 (1904). See Developments 949-51, for a short history of pre-1938 discovery procedure.

11. In 1934, Congress passed the Rule-making Act which gave the Supreme Court power to prescribe rules of procedure for the federal district courts and, in particular, to unite law and equity. Act of June 19, 1934, ch. 651, §§ 1-2, 48 Stat. 1064 . On June 3, 1935, the Court appointed the "Advisory Committee" to draft the rules, 295 U.S. 774-75 (1935), and on December 20, 1937, the Court promulgated the Federal Rules of Civil Procedure, 302 U.S. 783 (1937). The Rules were reported to Congress and, in accordance with rule 86, became effective (three months after Congress' "adjournment") on September 16, 1938. 1B MOORE T .523[5].

See generally 1B MOORE TI .501-.528 for a history of federal rule-making. 
discovery devices ${ }^{12}$ for securing information or material "relevant to the subject matter involved in the pending action."13 The unrestricted nature of these new discovery techniques resulted in unforeseen difficulties. While the discovery provisions mandated complete disclosure, the characteristics of the adversary system were such that an attorney was reluctant to reveal anything to his opponent, especially the fruits of his own labor. ${ }^{14}$ Consequently, demands for discovery of materials prepared by an attorney in preparation for trial-the attorney's work product ${ }^{15}$ - did not go unchallenged.

Before 1947, the cases dealing with a lawyer's trial-preparation materials were inconsistent both in their holdings and in their analyses. $^{16}$ The inajority of courts denied discovery, though on a variety

12. Fed. R. Civ. P. 26-37. Rule 26 , in its present form, is a general provision which outlines the methods and scope of discovery. Rules 27-32 govern the taking of depositions upon oral examination or written questions. Rule 33 provides for written interrogatories to parties, and rule 34 permits the production of documents and entry upon land for inspection. Rule 35 makes provision for mental or physical examination of parties, and rule 36 governs requests for admissions. Rule 37 provides sanctions for failure to grant discovery.

13. FrD. R. Civ. P. 26(b)(1). Relevance in this context is not limited to materials relevant to the merits of the action. It extends to preparatory materials also. See 4 MOORE T 26.56[1], at 26-117.

14. See Comment, Ambiguities After the 1970 Amendments to the Federal Rules of Civil Procedure Relating to Discovery of Expert's and Attorney's Work Product, 17 WAYNe L. Rev. 1145, 1149 (1971). Complete disclosure appears inconsistent with the effective functioning of the adversary system. See Cooper 1275. In fact, much of the value of some devices of trial strategy is thought to be in surprise. Id. at 1295. Cf. LaFrance, Work-Product Discovery: A Critique, 68 Dick. L. Rev. 351, 369 (1964). ("The Court's desire in Hickman to protect attorneys seems to be based on one preinise. The preinise is that an attorney prepares for trial only to surprise his adversary.")

It might be argued that complete disclosure would simply move trial tactics ont of the courtroom back to the discovery stage of the litigation. That is, each counsel would learn his opponent's contentions, both legal and factual, and his proposed tactics, to such an extent that the only function of the trial itself would be to lay the matter before the trier of fact for a final decision. But such a process might easily lead to complete cooperation between counsel, a practice arguably inconsistent with the concept of adversariness which underlies much of the Anglo-American legal system.

15. Technically, work product is whatever preparatory materials are protected under the deeision in Hickman v. Taylor, 329 U.S. 495 (1947). See notes 23-63 infra and accompanying text. The Hickman opinion does provide a general description of what might constitute work product:

Proper preparation of a client's case demands that [the lawyer] asseinble information, sift what he considers to be the relevant from the irrelevant facts, prepare his legal theories and plan his strategy without undue and needless interference .... This work is reflected, of course, in interviews, statements, ineinoranda, correspondence, briefs, mental impressions, personal behefs, and countless other tangible and intangible ways. Id. at 511 .

16. Between the adoption of the Federal Rules in 1938 and the Supreme Court's landinark decision in Hickman v. Taylor, 329 U.S. 495 (1947), there were more than sixty decisions dealing with the work product issue. See 4 MOORE If 26.63[4]. The 
of different grounds. ${ }^{17}$ At least one court noted the possible detrimental effect of discovery on the lawyer-chent relationship and therefore accorded the lawyer's work the status of privileged material, that is, not subject to discovery under any circumstances. ${ }^{18}$ According to another view, however, the policy of the Federal Rules that cases should be decided on the basis of all the facts required unlimited discovery. ${ }^{19}$ Because of this uncertainty, the Advisory Committee on

term "work product" itself apparently was not used until the circuit opinion in Hickman, 153 F.2d 212 (3d Cir. 1945). Evidently the phrase was coined in oral argument, as the court said:

This was talked about as the "work product of the lawyer" in the argument of the case. This is a phrase which seems pretty well to describe what we are after, though we hesitate to adopt it as a label for our concept for fear that it may contain implications not now apparent to us. It does with fair accuracy describe what we are excluding here under the term privilege. Id. at 223.

17. Some courts held the matter sought nondiscoverable because it would not be admissible into evidence. See, e.g., Matthies v. Peter F. Connolly Co., 2 F.R.D. 277 (E.D.N.Y. 1941) (hearsay testimony cannot be taken in a deposition); Poppino v. Jones Store Co., 1 F.R.D. 215, 217 (W.D. Mo. 1940) (same holding); Kenealy v. Texas Co., 29 F. Supp. 502, 504 (S.D.N.Y. 1939) (statements made after the accident do not constitute material evidence). One court, in an often quoted statement, said that to permit discovery of such materials "would penalize the diligent and place a premium on laziness," a result the drafters of the discovery provisions did not intend. McCarthy v. Palıner, 29 F. Supp. 585, 586 (E.D.N.Y. 1939). Still others held that any matter obtained after the commencement of the action should not be subject to discovery. See, e.g., Stanley Works v. C.S. Mersick \& Co., 1 F.R.D. 43, 46 (D. Conn. 1939); Murphy v. New York \& Puerto Rico S.S. Co., 27 F. Supp. 878, 880 (S.D.N.Y. 1939). Contra, Stark v. American Dredging Co., 3 F.R.D. 300, 301 (E.D. Pa. 1943) (to inake such a distinction between statements obtained before suit began and those obtained thereafter would be illogical). For a discussion of the cases prior to Hickman, see Advisory Committee on Rules for Civil Procedure, Report of Proposed Amendments to Rules of Civil Procedure for the District Courts of the United States, reported in 5 F.R.D. 433, 457-60 (1946); 4 Moore $\Uparrow 26.63[4] ; 8$ WRIGHT \& MiLleR $\S 2021$.

The Rules now make it clear that "[i]t is not ground for objection that the imforInation sought will be inadmissible at the trial if the information sought appears reasonably calculated to lead to the discovery of admissible evidence." FeD. R. CIv. P. 26(b) (1). Furthermore, no distinction can properly be made between materials obtained before commencement of the action and those obtained later. See Stix Prods., Inc. v. United Merchants \& Mfrs., Inc., 47 F.R.D. 334, 337 (S.D.N.Y. 1969); Ownby v. United States, 293 F. Supp. 989, 990 (W.D. Okla. 1968); Tame, Discovery of Trial Preparations in the Federal Courts, 50 ColuM. L. REv. 1026, 1039-41 (1950).

18. Hickman v. Taylor, 153 F.2d 212 (3d Cir. 1945), cert. denied, 327 U.S. 808, vacated, 328 U.S. 876 (1946), aff'd on other grounds, 329 U.S. 495 (1947). See also Thiel v. Southern Pac. Co., 6 F.R.D. 219, 221 (N.D. Cal. 1946).

19. See Seligsou v. Camp Westover, Inc., 1 F.R.D. 733 (S.D.N.Y. 1941). See also Hoffman v. Palmer, 129 F.2d 976 (2d Cir. 1942), aff'd on other grounds, 318 U.S. 109 (1943), where the court said:

Some lawyers also grumble, saying that it is "unfair" that a lawyer ... should be obliged to let counsel for the adversary scrutinize his data. But ... "unfaimess" to a diligent lawyer is of no importance as against much- 
Rules for Civil Procedure ${ }^{20}$ proposed an amendment to the Federal Rules which provided conditional protection to writings prepared in anticipation of litigation and absolute privilege to any writings that reflected an attorney's mental processes. ${ }^{21}$ The Supreme Court, however, failed to adopt this amendment, choosing instead to promulgate its solution in the form of a judicial opinion. ${ }^{22}$

\section{Hickman v. Taylor}

The issue decided by Hickman v. Taylor ${ }^{23}$ arose when the administrator of the estate of one of the deceased crew nembers of a sunken tugboat brought suit under the Jones $\mathrm{Act}^{24}$ and sought discovery of written statements taken from the survivors of the mishap by counsel for the defendant ship coinpany and memoranda prepared by the

needed improvement in judicial ascertainment of the "facts" of cases ....

Id. at 997 (dictum).

20. The original Advisory Committee was appointed by the Supreme Court ouly to draft the initial Federal Rules. Sce note 11 supra. In 1942, however, the Court appointed as many of the surviving members of the original committee "as [were] willing to serve" on a continumg Advisory Committee "to advise the Court with respect to proposed amendments or additions to the Rules of Civil Procedure . . ." 314 U.S. 720 (1942). Later, pursuant to an act of Congress authorizing continuous study of the Federal Rules, 28 U.S.C. $\$ 331$ (1970), the Chief Justice appointed a Standing Coinmittee on Rules of Practice and Procedure to which the Advisory Coinmittee on Rules for Civil Procedure would report regarding proposed ameudments. Eventually, the Court must approve the ameudinents. See 1B MoORE $\mathbb{T} .529$ (1973 Supp.).

21. The amendinent provided for the addition of the following two senteuces to former rule $30(\mathrm{~b})$ :

The conrt shall not order the production or inspection of any writing obtained

or prepared by the adverse party, his attorney, surety, indeinnitor, or agent in anticipation of litigation or in preparation for trial unless satisfied that denial of production or inspection will unfairly prejudice the party seeking the production or inspection in preparing his claim or defense or will cause hiln undue hardship or injustice. The court shall not order the production or inspection of any part of the writing that reflects an attorney's inental inpressions, conclusions, opinious, or legal theories, or, except as provided in Rule 35 , the conclusions of an expert.

Advisory Committee on Rules for Civil Procedure, supra note 17, at 456-57. Note the similarity between this proposal and rule 26(b)(3) adopted twenty-four years later. The text of rule $26(\mathrm{~b})(3)$ is set out in note 65 infra.

22. Hickman v. Taylor, 329 U.S. 495 (1947). Why the Court preferred to make its pronouncement in an opinion rather than by adopting the amendment is a matter of speculation. From a practical point of view, a judicial opinion would seem to be a better medium in which to fully develop the new standard and the rationale behind it. Furthermore, by the time that the final version of the proposed ainendment had been reported to the Supreme Court (June 1946, 1B Moore II .525[1]), the Court had already decided to hear the case (May 27, 1946). 328 U.S. 876, vacating 327 U.S. 808 (1946). Thus, it was appropriate to defer consideration of the amendment. See Tolman, Discovery Under the Federal Rules: Production of Documents and the Work Product of the Lawyer, 58 CoLUM. L. REv. 498, 507 (1958).

23. 329 U.S. 495 (1947).

24. 46 U.S.C. $\S 688$ (1970). 
same attorney froin interviews of other witnesses. ${ }^{25}$ Plaintiff's lawyer frankly admitted that he wanted the statements "only to help prepare himself to examine witnesses and to make sure that he has overlooked nothing."26 When defendant's counsel refused to obey the order of the district court to produce them, ${ }^{27}$ he was adjudged in criminal contempt. On appeal, ${ }^{28}$ the Court of Appeals for the Third Circuit reversed on the ground that the information sought was privileged. ${ }^{20}$ In one of the most significant decisions involving the Federal Rules, the Supreme Court affirmed. However, the Court clearly rejected the idea that the attorney-client privilege ${ }^{30}$ might apply in such circumstances. ${ }^{31}$ Nevertheless, Justice Murphy, in his majority opinion, asserted that

[n]ot even the most liberal of discovery theories can justify unwar-

25. Defendant's counsel took statements from the survivors between one and two months after the accident. He also interviewed other persons and in some instances made memoranda of what he learned. Plamtiff brought suit more than eight months after the accident and, by interrogatories, sought production of both the statements and the memoranda. At that time, the witnesses were still available, and their testimony taken at an investigatory hearing within one month after the accident was on record. 329 U.S. at 498-99.

See Discovery Procedure Symposium, 5 F.R.D. 403, 408-13 (1946), where the Hickman case is discussed just prior to oral argument before the Supreme Court. Defendant's counsel, Samuel Fortenbaugh, gives his own account of the facts there.

26. 329 U.S. at 513.

27. Hickman v. Taylor, 4 F.R.D. 479 (E.D. Pa.), rev'd, 153 F.2d 212 (3d Cir. 1945), cert. denied, 327 U.S. 808, vacated, 328 U.S. 876 (1946), aff'd on other grounds, 329 U.S. 495 (1947).

28. The appeal was taken from the contempt judgment. Appeal was allowed because under federal procedure that judgment was a final order. See Hickman v. Taylor, 153 F.2d 212, 214 (3d Cir. 1945), cert. denied, 327 U.S. 808, vacated, 328 U.S. 876 (1946), aff'd on other grounds, 329 U.S. 495 (1947). See note 95 infra.

29. [There is] a feeling on the part of judges that "privilege" as the term

is used in the Federal Rules and "privilege" as one fimds the term in the law of evidence as a ground for excluding testimony are not identical. We agree.

$$
\text { -.. }
$$

We are clear in our own minds ... that "privilege" as used in the Rules comprehends the material asked for in the interrogatory . . namely, memoranda of talks with witnesses, signed statements made by witnesses, the lawyer's recollection of talks with witnesses. 153 F.2d at 222-23.

30. Wigmore gives the following definition of the attorney-client privilege:

(1) Where legal advice of any kind is sought (2) from a professional legal advisor in his capacity as such, (3) the communications relating to that purpose, (4) made in confidence (5) by the client, (6) are at his instance permanently protected (7) from disclosure by himself or by the legal advisor, (8) except the protection may be waived. $8 \mathrm{~J}$. WIGMORE, EVIDENCE IN Trinls AT CoMMON LAW \& 2292 (1961).

31. 329 U.S. at 508: "We also agree that the memoranda, statements and mental impressions in issue in this case fall outside the scope of the attorney-client privilege and hence are not protected from discovery on that basis."

The inaterials sought foll outside the scope of the attorney-client privilege because they did not relate to communications between attorney and client; rather, they related to communications between attorney and witnesses. 
ranted inquiries into the files and the mental impressions of an attorney.

... Proper preparation of a client's case demands that he assemble information, sift what he considers to be the relevant from the irrelevant facts, prepare his legal theories and plan his strategy; without undue and needless interference. ${ }^{32}$

The Court went on to qualify this conclusion:

We do not mean to say that all written materials obtained or prepared by an adversary's counsel with an eye toward litigation are necessarily free from discovery in all cases. Where relevant and non-privileged facts remain hidden im an attorney's file and where production of those facts is essential to the preparation of one's case, discovery may properly be had. ${ }^{33}$

With regard to the written statements, the Court determined that while the Rules gave the trial judge sufficient discretion to deal with the problem, "a naked, general demand for these materials as of right . . . was insufficient to justify discovery under these circumstances . . . ."34 The Court went further, however, with regard to the oral statements made to defendant's counsel:

[W] anda, we do not believe that any showing of necessity can be made under the circumstances of this case so as to justify production .... ... If there should be a rare situation justifymg production of these matters, petitioner's case is not of that type. ${ }^{35}$

Thus, Hickman made clear that some materials prepared by a lawyer in anticipation of litigation will be "prima facie" protected from discovery. ${ }^{36}$ However, it is also clear that if the imquiring party makes a showing of "good cause,"

32. Id. at $510-11$.

33. Id. at 511. Because of the record from the investigatory hearing and the continuing availability of witnesses, the plaintiff's lawyer could hardly argue that the material that he sought was essential. See note 25 supra.

34. Id. at 512.

35. Id. at 512-13.

36. Developments 1029.

37. Prior to the 1970 amendments, "good cause" in this context was referred to as "extra good cause" to distinguish it from the "good cause" requirement of rule 34 dealing with the production of documents. See Cooper 1273. The 1970 amendments eliminated "good cause" from rule 34 because of the confusion it created. See Advisory Committee on Rules for Civil Procedure, Proposed Amendments to the Federal Rules of Civil Procedure Relating to Discovery, reported in 48 F.R.D. 487, 526-27 (1970). The amendments also codified the standard for discovery of work product in rule 26(b)(3). See note 65 infra. See also Comment, supra note 14, at 1156-57; Note, Federal Discovery Rules: Effects of the 1970 Amendments, 8 CoLum. J.L. \& SOC. PROBLEMS 623, 628 (1972). 


\section{The Hickman Rationale}

Despite this Supreme Court pronouncement, the courts have continued to reach conflicting decisions, ${ }^{38}$ though perhaps the range of disagreement has been narrowed. This conflict can probably be attributed to an uncertainty about the rationale underlying the Hickman decision. ${ }^{39}$ To discern that rationale, it is helpful to examine the analytic framework adopted by the Hickman Court.

The Court's objective was presumably to facilitate the just and efficient functioning of our judicial system. ${ }^{4 a}$ In furtherance of this goal, the Federal Rules had contemplated full disclosure of information between the parties to a lawsuit. ${ }^{41}$ But complete disclosure, the Court asserted, would impede the functioning of counsel ${ }^{42}$ by blunting the adversariness that is inherent in the judicial system. ${ }^{43}$ Therefore, the Court suggested an equation to balance these competing interests. ${ }^{44}$ On one side of the equation is the need to accominodate the adversary system by protecting certain materials prepared by a lawyer in anticipation of litigation; the "weight" to be attached to this interest may be seen as varying with one's assessinent of the extent to which greater discovery will cause undesirable consequences to the adversary system.

38. Compare Alltmont v. United States, 177 F.2d 971 (3d Cir. 1950) (construing ADMIRALTY Rules 31 \& 32, which are counterparts to Fed. R. Civ. P. 33 \& 34; matcrials procured by persons under the direction of counsel in preparation for trial are protected as work product) with E.I. DuPont de Nemours \& Co. v. Phillips Petroleum Co., 24 F.R.D. 416 (D. Del. 1959) (work product rule applies only when the lawyer gathered the materials in preparation for trial). Compare United States v. Aluminum Co. of America, 34 F.R.D. 241 (E.D. Mo. 1963) (in civil antitrust suit, responses to questionnaires are protected where they contain confidential business data) with Seven-Up Co. v. Get Up Corp., 30 F.R.D. 550 (N.D. Ohio 1962) (in action for trademark infringement, responses made in interviews concerning trademark confusion are discoverable).

39. See Cooper 1272 ("the opinion consists of a vague amalgam of references to 'injustice' and 'hardship" "); LaFrance, supra note 14, at 366 ("the Court did not define work product adequately"); Comment, Basic Survey of Work Product in Federal and State Jurisdictions in Civil and Criminal Proceedings, 35 TENN. L. Rev. 474, 495 (1968) (the difficulty lies in "defining the exact nature and scope of the work product doctrine").

40. The Federal Rules "shall be construed to secure the just, speedy, and inexpensive determination of every action." FED. R. CIV. P. 1. The Hickman Court, in referring to the role of the lawyer in the judicial system, used such phrases as "the orderly prosecution and defense of legal claims," 329 U.S. at 510, "to promote justice," id. at 511 , and "an orderly working of our system of legal procedure," id. at 512.

41. See notes 12-13 supra and accompanying text.

42. See note 46 infra and accompanying text.

43. See note 14 supra and accompanying text. Presumably, litigation in an adversary context contributes just as much to effective truthseeking as would free discovery.

44. 329 U.S. at 510-14. 
On the other side is the policy of the Rules for disclosure; the "weight" of this interest will vary with the need of the inquiring litigant for the information. As one court stated:

The privilege of the lawyer's work product and the showing of good cause sufficient to overcome it are interdependent, and when, as here, the factors supporting the claim of privilege are weak, the requisite showing of good cause is correspondingly lessened. 45

The equation thus permits as much disclosure as is consistent with the adversary system's need for privacy. In determining how much disclosure to allow, the greatest difficulty lies in ascertaining what consequences will flow from unrestricted discovery, and how deleterious those consequences will be. The Hickman Court merely assumed that certain undesirable effects would, in fact, occur. ${ }^{46}$ Since the commentators disagree as to what, if any, consequences non-protection of work product might have, ${ }^{47}$ and not all courts have accepted the Supreme Court's assertion that detrimental effects would actually result from unlimited discovery, ${ }^{48}$ it will be helpful, before reaching a conclusion

45. United States v. Swift \& Co., 24 F.R.D. 280, 284 (N.D. Ill. 1959). See also Harper \& Row Publishers, Inc. v. Decker, 423 F.2d 487 (7th Cir. 1970), aff'd by an equally divided court, 400 U.S. 348 (1971): "[T] $]$ he less the lawyer's 'mental processes' are involved, the less will be the burden to show good cause." Id. at 492.

46. Were such materials open to opposing connsel on mere demand, much of what is now put down in writing would remain unwritten. An attorney's thoughts, heretofore imviolate, would not be his own. Inefficiency, unfairness and sharp practices would inevitably develop in the giving of legal advice and in the preparation of cases for trial. The effect on the legal profession would be demoralizing. And the interests of the clients and the cause of justice would be poorly served. 329 U.S. at 511 .

47. Some commentators remain faithful to the Hickman opinion and contend that protection should be granted to work product in order to avoid deterrence of adequate preparation. See note 58 infra and accompanying text.

One cominentator has denied that the consequences of unrestricted discovery expressed in Hickman are realistic factors to be considered. See Cooper 1276-82. He maintained that the danger of free discovery lies in the effect it would have on the trial itself: "[P]erfect knowledge of every item of proof and argument . . . would often result . . . in a development of position and response calculated to inpede rather than advance the search for . .. truth ...."Id. at 1275. This naturally led hin to the conclusion that the major concern of the work product doctrine should be the protection of trial tactics. Id. at 1275, 1296. But cf. Sannders v. United States, 316 F.2d 346, 350 n.3 (D.C. Cir. 1963) ("It may be true that the work prodnct rule reflects considerations other than maintaining the privacy of the attorney's thoughts and trial tactics.")

Another commentator has nrged that Hickman was wrongly decided and that nothing other than privileged material should be immune from discovery. See LaFrance, supra note 14.

48. See, e.g., Southern Ry. v. Lanham, 403 F.2d 119, 129 (5th Cir. 1968) ("It is not likely that defendants in accident cases will cease taking statements simply to avoid discovery"); American Express Warehousing, Ltd. v. Transamerica Ins. Co., 380 F.2d 277 (2d Cir. 1967) (discovery of witness statements allowed). "[T]here is . . . the 
about the appropriate interpretation of Hickman, to examine some of the rationales that have been suggested as underlying the holding in that case.

First, it has been suggested that discovery of a lawyer's pretrial preparation materials might discourage him from "exerting his fullest efforts to develop his client's case." ${ }^{30}$ The theory is that a lawyer, fearing the discovery of evidence that lie might uncover supporting his adversary's case, might curtail his imvestigation witl respect to certain issues. Those who reject this conclusion argue that a lawyer must know the strengths and weaknesses of his case for settlement purposes and dare not risk going to trial unprepared. ${ }^{50}$ It would seem, however, that the real fear is not that a lawyer will be totally unprepared to present his client's case, but rather that there is a possibility that he will be discouraged from expending the last increinent of effort that should be characteristic of the adversary system and of a professionally responsible bar.

Another analysis assumes that unlimited discovery would deter the lawyer from reducing to writing much that should be recorded for effective preparation. ${ }^{51}$ With respect to the formal statements of witnesses that could be used at trial for impeachment, this assumption seems unpersuasive, since the need to tie the witnesses to one version of a story would appear to outweigh any fear of discovery. ${ }^{62}$ Deterrence of written preparation would seem to be a more realistic fear, however, with respect to a lawyer's mental impressions. By relying on his memory, imstead of committing his opimions to a memorandum, a lawyer could avoid produotion of a writing which might reveal a def-

possibility of . . . encouragement of lazy preparation . . . . That possibility may exist in a particular case, although we regard it as most improbable in this hotly contested litigation." Id. at 281-82. Compare these holdings with the Hickman Court's list of undesirable effects supposedly resulting from unrestricted discovery (e.g., much of what is written would remain unwritten). See note 46 supra.

49. Developments 1029. See Taine, supra note 17, at 1063 ("danger that fear of discovery will lead to the omission of important tasks ordinarily attended to by nonattomeys and thus to a lowering of the level of trial preparation"); Comment, stupra note 39 , at 475-76.

This justification finds some support in the Hickman opinion in that "inefficiency" im trial preparation is one of the evils wamed against. 329 U.S. at 511 .

50. F. JAMES, Civil Procedure § 6.9, at 206 (1965); Cooper 1280-82.

51. Developments 1029. See Comment, supra note 39 , at $475-76$. There is a definite basis for this position in the Hickman opinion. See note 46 supra.

Furthermore, if Hickman is read as distinguishing between written statements and oral recollections, with greater protection from discovery afforded the latter, see 329 U.S. at $512-13$, then that case may exacerbate the problem discussed in the text by providing further disincentives for preserving statements in writing.

52. See F. James, Civil Procedure § 6.9, at 206 (1965); Cooper 1277-79. 
inite and detailed statement of his professional judgment. It would be difficult, as a practical matter, to obtain such information from him by means of deposition or written interrogatiory with any degree of certainty or precision. ${ }^{53}$ On the other hand, failure to reduce his impressions to writing would very likely decrease the attorney's efficiency.

A third rationale for the Hickman holding, propounded in the opinion itself, is a fear of the development of "sharp practices"54 if discovery were to remain unrestricted. It has been suggested that these might imclude a lawyer's placement of misleading memoranda in his own files for his opponent to discover ${ }^{55}$ and a lawyer's denial of the existence of evidence he had collected in preparation for hitigation when he felt that his misstatement would not subsequently be detected. ${ }^{56}$ Of course, the danger of unethical conduct exists in regard to discovery of any type of information, not merely to that of trial preparation materials; ${ }^{57}$ however, to the extent that allowing discovery of work product would make sharp practices more likely, perhaps the potential for unethical conduct should be considered as a justification for affording work product protection.

Though it is difficult to enunciate a single rationale for the Hickman holding, the justification most frequently invoked by the commentators for protecting work product is that unrestricted discovery would deter adequate preparation. ${ }^{58}$ This is a synthesis of the "deter-

53. If, for instance, a party were asked about his interpretation of the facts concerning the matter in dispute, or asked about the versiou of the facts he would espouse at trial, he could, in most cases, reply in good conscience that he had not yet decided upon a particular interpretation. Thus, he could probably give some honest response that would not give away his trial strategy. However, if a meinorandum concerning the matter had beeu written by the lawyer for his own benefit, there is no doubt that his opponent could draw certain inferences from it as to his proposed plans for trial. If the lawyer feared disclosure of such plans, it is unlikely that he would write the memo.

Of course, if the opponent asked a direct question about a fact in the case, no "evasive" answer would be available. However, the work product doctrine is inteuded to protect the fruit of the attorney's labors, not the factual information intermingled with it. See Cleary, Hickman v. Jencks: Jurisprudence of the Adversary System, 14 VAND. L. REV. 865, 868 (1961).

54. 329 U.S. at 511. But see Cooper 1276; Developments 1028. "[T]he rationale for the work-product doctrine rests not so much on the fear of unfairness or sharp practices as on the desire to proinote the effectiveness of the adversary system . . . " Id.

55. See Cleary, supra note 53, at 869.

56. See Gardner, Agency Problems in the Law of Attorney-Client Privilege: Privilege and "Work Product" Under Open Discovery (Part II), 42 U. DEr. LJ. 253, 269 (1965).

57. Cooper 1276.

58. See, e.g., Gardner, supra note 56, at 268; Taine, supra note 17, at 1042; Developments 1028-29. 
rence from adequate investigation" and the "deterrence from written preparation" theories already discussed. However, it is possible to formulate a broader proposition regarding Hickman which encompasses most of the possible rationales suggested here ${ }^{50}$ and elsewhere. ${ }^{60}$ Such a proposition would be based on the observation that all of the evils that are feared from unrestricted discovery can occur only because the lawyer anticipates that his preparatory materials will be discovered. That is, the Hickman Court suggested that if attorneys know that their work product is subject to discovery, they will behave in a manner necessarily harmful to the adversary system. Whether this interference with the adversary process appears in the form of inadequate preparation or as "sharp practices" is not important here. It is enough to realize that the consequences sought to be avoided would occur because of what the lawyer anticipates at the time of preparation, ${ }^{61}$ and not as a result of discovery itself. ${ }^{62}$ While this "rationale" does nothing to advance the definition of what in fact constitutes work product, ${ }^{63}$ it does set forth the theory upon which protection of preparatory materials ought to be based, and this theory is sufficient to provide the answer to the question of whether discovery of work product should be allowed in subsequent litigation.

\section{Discovery of Work Product in Subsequent Litigation}

One of the unresolved issues relating to the work product doctrine is whether protection from discovery should be extended to work product generated in an earlier suit. ${ }^{84}$ Before entering upon any dis-

59. See notes 49-57 supra and accompanying text.

60. Another negative result of unlimited discovery set forth in Hickman is the "demoralizing" effect on the legal profession. 329 U.S. at 511. Presumably this implies that attorneys would be generally demoralized because they would be painfully aware of the fact that whatever preparation they engaged in might not be capable of effective utilization at trial, since their opponents would have access to their materials and could counter any strategy that was planned.

61. It may be that most of the undesired consequences relate to preparation (i.e., they will occur at the time of preparation); lowever, not all of those consequences reflect inadequate preparation. For example, the sharp practices feared by the Court would presumably take place during the preparation and discovery period, see notes 54 57 supra and accompanying text, but they are not necessarily inconsistent witll adequate preparation.

62. For an example of a rationale for protecting work product based on supposed direct effects of unrestricted discovery upon the trial process itself, see note 47 supra. Whatever the merits of this approach, it is not the one adopted by the Hickman Court.

63. It is still necessary to determine those materials, discovery of which will cause the undesired effects.

64. By way of introduction, it should be made clear that the issue of whether to allow discovery of work product in litigation subsequent to that for which it was pre- 
cussion of the cases, however, it should be made clear that the Federal Rules themselves do not provide any clear solution to this problem. Rule 26(b)(3), ${ }^{65}$ a codification of the Hickman case, ${ }^{66}$ affords protection to materials "prepared in anticipation of litigation." It could be argued that "Iitigation" in the rule means only this litigation; ${ }^{67}$ that is, only materials prepared specifically for the case at bar qualify for work product protection. A second, somewhat more persuasive reading of the rule is based on the longer clause "prepared in anticipation of litigation or for trial by or for another party." tion of that clause would lead to two results. First, protection would be extended only to an attorney representing a party-a participant in the present suit. An "outside" attorney not imvolved in the litigation could be made to surrender all his relevant files. Second, if the materials sought were prepared for a present party in anticipation of earlier litigation, they would be protected. ${ }^{99}$ However, these conclu-

pared has received little attention. Very few courts have dealt with the problem and those that have, have given it only superficial consideration. See, e.g., Honeywell, Inc. v. Piper Aircraft Corp., 50 F.R.D. 117 (M.D. Pa. 1970); Philadelphia Elec. Co. v. Anaconda Am. Brass Co., 275 F. Supp. 146 (E.D. Pa. 1967).

65. Rule 26(b) (3) states:

Trial Preparation: Materials. Subject to the provisions of subdivision (b) (4) of this rule, a party may obtain discovery of documents and tangible things otherwise discoverable under subdivision (b)(1) of this rule and prepared in anticipation of litigation or for trial by or for another party or by or for that other party's representative (including his attorney, consultant, surety, indemnitor, insurer, or agent) only upon a showing that the party seeking discovery has substantial need of the materials in the preparation of his case and that he is unable without undue hardship to obtain the substantial equivalent of the materials by other means. In ordering discovery of such materials when the required showing has been made, the court shall protect against disclosure of the mental impressions, conclusions, opinions, or legal theories of an attorney or other representative of a party concerning the litigation.

A party may obtain without the required showing a statement concerning the action or its subject matter previously made by that party. Upon request, a person not a party may obtain without the required showing a statement concerning the action or its subject matter previously made by that person. If the request is refused, the person may move for a court order. The provisions of Rule 37(a) (4) apply to the award of expenses incurred in relation to the motion. For purposes of this paragraph, a statement previously made is (A) a written statement signed or otherwise adopted or approved by the person making it, or (B) a stenographic, mechanical, electrical, or other recording, or a transcription thereof, which is a substantially verbatiun recital of an oral statement by the person making it and contemporaneously recorded. Fed. R. CIV. P. 26(b) (3).

66. Duplan Corp. v. Moulinage et Retorderie de Chavanoz, 487 F.2d 480, 482 (4th Cir. 1973); 8 WRIGHT \& MILLER $§ 2023$, at 193. See generally Comment, supra note 14 , at 1157-63.

67. See Thill Sec. Corp. v. New York Stock Exch., 57 F.R.D. 133, 138 (E.D. Wis. 1972) ("I consider work product to be material prepared in preparation for this case, not just material gathered with the knowledge that it might be used in some future litigation.")

68. Fed. R. Civ. P. 26(b) (3).

69. See 8 WRIGHT \& MILLER $§ 2024$, at 201-02, \& n.29. 
sions could lead to absurd results. ${ }^{70}$ Neither of the above interpretations has been seriously considered by the courts. Since the rule was apparently drafted without consideration of the "subsequent hitigation" problem, ${ }^{71}$ the courts should base their decisions on Hickman. ${ }^{72}$

When the courts have been faced with this issue, ${ }^{73}$ they have utilized three different approaches. Under the first approach, enunciated in Hanover Shoe, Inc. v. United Shoe Machinery Corp. ${ }^{74}$ and Honeywell, Inc. v. Piper Aircraft Corp., ${ }^{75}$ discovery of inaterials prepared in one suit is allowed without question in a later suit. In the Honeywell case, which is typical of those involving the "subsequent litigation" issue, plaintiff Honeywell sued Piper and another company for patent infringement. In discovery, defendants sought a number

70. Suppose $A$ and $B$ brought separate suits against $C$ on the same grounds. Under the interpretation suggested in the text, $C$ could effect discovery of A's attorney's work product through discovery proceedings in the suit against B. Such a result is clearly undesirable. $I d$. at 202.

71. Duplan Corp. v. Moulinage et Retorderie de Chavanoz, 487 F.2d 480, 482 (4th Cir. 1973). See Advisory Committee on Rules for Civil Procedure, supra note 37, at 499-503.

72. See Duplan Corp. v. Moulinage et Retorderie de Chavanoz, 487 F.2d 480, 482 (4th Cir. 1973).

73. Initially, one group of cases must be distinguished from the other cases dealing with discovery of work product materials generated in prior litigation. These are cases in which information sought to be discovered involves the behavior and conduct of the attorney in the prior suit rather than facts related to substantive issues. In a typical case, the insurer's attorney, representing a policy holder in tort litigation, fails to settle within policy limits and then loses the case. The former defendant-policy holder then sues to recover the excess of the judgment over the policy limit, claiming bad faith on the part of the insurance company, and seeking discovery of correspondence between the insurer and its attorneys. In such cases, discovery has universally been granted; because it is very likely that the correspondence sought will be dispositive evidence in the second suit, the requisite "substantial need" and "undue hardship" of rule $26(b)(3)$, see note 65 supra, will invariably be found by the court. See, e.g., Bourget v. Government Einployees Ins. Co., 48 F.R.D. 29 (D. Conn. 1969); LaRocca v. State Farm Mut. Auto. Ins. Co., 47 F.R.D. 278 (W.D Pa. 1969); Kirkland v. Morton Salt Co., 46 F.R.D. 28 (N.D. Ga. 1968) (suit for malicious use of process in garnishment of debt allegedly paid in full); Chitty v. State Farm Mut. Auto. Ins. Co., 36 F.R.D. 37 (E.D.S.C. 1964). Consequently, the issue of whether the material is technically work product for purposes of the second suit is unimportant.

74. 207 F. Supp. 407 (M.D. Pa. 1962). In Hanover, the plaintiff brought an antitrust action against United Shoe seeking treble damages. In a previous case, an antitrust action by the United States against United Shoe, one of the defendant's lawyers prepared a memorandum following a meeting in which the president of Hanover was interviewed. In the second suit, plaintiff sought discovery of this memorandum and defendant claimed work product protection. The court permitted discovery, stating that

[t]here is nothing in the Hickman case which extends the work product prin-

ciple to preclude discovery of a lawyer's memorandum, prepared during a prior case, in a subsequent action between different parties. Id. at 410 .

75. 50 F.R.D. 117 (M.D. Pa. 1970). The Hanover and Honeywell cases were both decided by Judge Sheridan. 
of documents related to prior patent interference cases (involving the same patents) tried before the Board of Patent Interferences of the United States. Although the plaintiff contended that the work product privilege should apply, the court permitted discovery, simply stating that "[t]here is no indication that the documents were prepared 'with an eye toward litigation' involved in this suit."'te This approach rests on too narrow an interpretation of the work product doctrine because it grants discovery of all relevant materials to the complete exclusion of the needs of the adversary system which the Hickman Court deemed so important. It is easy to imagine a situation in which a lawyer would anticipate attempted discovery, in future litigation, of his present work product. ${ }^{77}$ If the attorney knows that discovery will be freely allowed, the potential is present for the undesirable conse-

76. 50 F.R.D. at 119 (emphasis added). Although it may seem that this statement indicates an adoption by the court of the interpretation of rule $26(\mathrm{~b})(3)$ suggested above, see note 67 supra and accompanying text, Honeywell was decided three days before that rule was adopted.

The Honeywell court may have adopted its approach as a result of a misapplication of the holding of an earlier case dealing with a similar issue but distinguishable on its facts. The earlier case, cited in both Hanover and Honeywell, was Tobacco \& Allied Stocks, Inc. v. Transamerica Corp., 16 F.R.D. 534 (D. Del. 1954). In that case, the plaintiff's attorney had represented another client in previous litigation. Both suits involved the same subject matter, and in both Transamerica was the defendant. At the time of the previous action, however, the attorney in question had not yet been retained by the plaintiff in the second suit. In the second suit, defendant sought production of some of the attorney's correspondence in the first action. The court properly permitted discovery. Id. at 537. This seems consistent with the Hickman rationale; the court's emphasis on the fact that the attorney had not been retained by the plaiutiff until after the termmation of the first suit implies that had the attorney, in fact, represented both clients at the time of the first suit, protection might have been granted. But since this was not the case, the attorney could not have foreseen the subsequent litigation. Therefore, he could not have anticipated discovery of his work product in the second case, and no basis existed for granting work product protection.

In Hanover and Honeywell, however, the party from whom discovery was sought had also been a party in the prior suit, and was represented by the same attorney in both actions. Hence there was a possibility that the attorney might have foreseen his involvement in the second suit, as part of his continuing representation of his cheut. Judge Sheridau ignored that distinction in both cases and simply cited Transamerica for the proposition that work product is not entitled to protection in subsequent litigation between differeut parties. 50 F.R.D. at 119, 207 F. Supp. at 410 , respectively. Note that the "different parties" in Hanover and Honeywell were the inquiring parties. If the basis for protection depends upon the attorney's anticipation of discovery of his work product, it appears to be irrelevant that "different parties" are doing the discovering.

77. An attorney representing the defendant against one victim in a mass tort (e.g., an airline crash) might justifiably expect later suits brought by other victims or their representatives. If so, and if the attorney feared discovery of his preparatory materials in the later actions, he might be expected to adjust his method of preparation. See Developments 1044. 
quences against which the Supreme Court has sought to guard. ${ }^{78}$ The approach taken by the courts in Hanover and Honeywell thus appears to ignore the teaching of Hickman.

A second group of cases, imphedly recognizing the shortcomings of the Hanover-Honeywell approach, has adopted a somewhat broader analysis, extending work product protection to subsequent closely related cases. ${ }^{79}$ That is, work product generated by an attorney in one action will not be subject to discovery in a later action if the two suits are closely related. ${ }^{80}$ Though not clearly enunciated, the justification for this rule seems to be that the evils feared by the Hickman Court are as likely to occur if discovery of work product is permitted in a subsequent, related suit as if it were permitted in the original case. ${ }^{81}$ Therefore the Hickman rationale would justify extending protection to work product in the "closely related" suit.

There are at least two difficulties inherent in this approach. First, although it has the advantage of flexibility, so that a trial judge could make a determination on the basis of the particular circumstances in each case, it lacks predictability because of the problem of determining what is "closely related." ${ }^{2}$ If the outcome of an attempt at discovery cannot be ascertained with some degree of certainty at the time of preparation for the original suit, attorneys will be uncertain as to future protection of their work and may very well adjust

78. See notes $32,42-43,46$ supra and accompanying text.

79. Midland Inv. Co. v. Van Alstyne, Noel \& Co., 59 F.R.D. 134 (S.D.N.Y. 1973); Philadelphia Elec. Co. v. Anaconda Am. Brass Co., 275 F. Supp. 146 (E.D. Pa. 1967); Insurance Co. of N. Am. v. Union Carbide Corp., 35 F.R.D. 520 (D. Colo. 1964).

80. Midland Inv. Co. v. Van Alstyne, Noel \& Co., 59 F.R.D. 134, 138 (S.D.N.Y. 1973) ("[M]aterials prepared for a prior litigation should not be discoverable in a later case wliere the two actions are closely related."); Philadelphia Elec. Co. v. Anaconda Am. Brass Co., 275 F. Supp. 146, 148 (E.D. Pa. 1967) ("That litigation is so closely related to the present litigation that the work product privilege would ordinarily extend to both.")

81. See Insurance Co. of N. Am. v. Union Carbide Corp., 35 F.R.D. 520 (D. Colo. 1964), where the court stated:

Adversary counsel in an active case, obviously, should not normally be free to force his opponent to reveal his strategy; but neither shonld counsel in a closely related subsequent case, albeit between different parties in part, obtain carte blanche to examine an attorney's files in the former case. Should discovery of an attorney's work product in a former case ever be generally or indiscriminately permitted counsel would undoubtedly feel constrained to leave unwritten and unrecorded many of their impressions and plans which they should feel free to reduce to writing. Id. at 522 .

82. If the "closely related" test were applied to the facts of Honeywell, a patent interference suit, the result would not be clear. If the same patent were involved in both original and subsequent cases, but a different aspect of it were at issue, what result? If the patent were similar to the one involved in the prior case? There are many variations in potential factual situations. 
their method of preparation; hence, the purpose of the work product doctrine will be frustrated. ${ }^{83}$

A second difficulty with the "closely related" approach is that it may protect a lawyer's work product in situations where protection seems unnecessary. This approach seens to be founded on the premise that if a subsequent case is closely related, the attorney, while preparing for the prior case, would likely have foreseen the possibility of future demands for discovery. Accordingly, the consequences sought to be avoided by the work product doctrine would flow naturally from the lawyer's anticipation of discovery, unless he knew that his work product would be granted protection from discovery. While this assumption may be accurate in many cases, it is not umiversally true. In some situations where a second, "closely related" suit is in fact litigated, the attorney may not have considered, at the time of the first suit, the possibility of discovery in a second suit or even the possibility of subsequent litigation; ${ }^{84}$ or if he considered either, he might have rejected those possibilities as too shght to concern him. In either event, the theoretical basis for work product protection would disappear. In short, the mere fact that two successive cases ${ }^{85}$ are

83. It would seem, therefore, that predictability is more important than flexibility. See 111-12 infra and accompanying text. This poses a question as to the validity of the test proposed later in this Note. See notes 107, 110-12 infra and accompanying text.

84. See note 76 supra.

85. What result if the first case has not yet been terminated? In Republic Gear Co. v. Borg-Warner Corp., 381 F.2d 551 (2d Cir. 1967), the plaintiff sought production of documents generated by the attorney of two South American companies when those companies were in the process of terminating their contracts with plaintiff Republic. Republic sought the documents to prove that defendant Borg-Warner had tortiously interfered with those contracts. However, in an earlier suit by Republic against the South American companies, these documents had been declared work product. The previous suit was pending on appeal and, furthermore, as the court pointed out, the South American companies might still be subject to suit in their own country. Id. at $557 \&$ n.5. Under these circuinstances, the court properly extended protection to the attorney's work product since to allow discovery before the first suit was completed would defeat the purpose of the doctrine.

One prerequisite to protection in a case like Republic Gear, where the "prior" action has not been terminated, is that the interests of the client whose attorney's work product is being sought must be adverse to those of the inquiring party. See Note, The Attorney's Trial Preparation and Pre-Trial Discovery Under the Federal Rules, 62 HaRv. L. Rev. 269, 274 (1948); cf. Shields v. Sobelmau, 64 F. Supp. 619 (E.D. Pa. 1946). It is clear that the interests in Republic were adverse since the inquiring party might still have sued the person seeking protection.

"Adverseness" in this context should not be equated with legal adverseness; that is, the persons seeking and objecting to discovery or those in privity with them should not have to be parties on opposing sides of the same lawsuit for protection to be available. If there is any significant danger that the material sought will be disclosed to 
closely related should not warrant automatic protection in the second suit of work product generated in the first. ${ }^{86}$

The third approach, recently propounded in Duplan Corp. $v$. Moulinage et Retorderie de Chavanoz ${ }^{87}$ represents the broadest apphcation of the work product doctrine to discovery in subsequent litigation. In Duplan, the Court of Appeals for the Fourth Circuit held that the work product of an attorney is protected from discovery in all subsequent litigation. Though the facts of the case are not clear, ${ }^{88}$ they are relatively unimportant in light of the court's view of the case. At the outset, the court framed the issue as

whether upon the termination of litigation the work product documents prepared incident thereto lose the qualified immunity extended to them

the adversary of the document producer, it should be protected unless some other safeguards can be taken. See Note, supra at 274. This conclusion is consistent with the Hickman rationale in that a "strict" standard of adverseness might not cover all situations in which an attorney might reasonably anticipate discovery of his work product.

86. On the other hand, the "closely related" test may also be too narrow in some respects. One can imagine a situation in which a lawyer does in fact anticipate discovery in a second suit which is not closely related to the first. Suppose such a lawyer represented a client who anticipated that he might be involved in two wholly unrelated lawsuits. Further suppose that in preparation solely for the first suit, the attorney wrote a short memorandum, perhaps for the benefit of his partner who would actually try the case, stating why he thought his client could easily be impeached as a witness at trial and the grounds for such impeachment. Certainly, opposing counsel in the second, unrelated suit would want to discover such a memorandum. Though it would not be admissible to impeach, it would be of great assistance in preparing his case. If the attorney who wrote the memorandum had considered the possibility of such discovery, he might have relied on his memory to inform his partner, at the sacrifice of efficient preparation.

87. 487 F.2d 480 (4th Cir. 1973).

88. The original litigation involved patent disputes between the defendant, a French corporation, and Leesona, a Massachusetts corporation, 487 F.2d at 481 n.2. The prior litigation ceased in 1964 when Leesona and defendant negotiated a "treaty." See Duplan Corp. v. Deering Milliken, Inc., 334 F. Supp. 703, 708 (D.S.C. 1971). Duplan-Chavanoz arose out of a patent-antitrust suit brought by a group of "throwsters" (the name relates to the type of machine involved in the patent litigation) allegedly aggrieved by certain patent licensing agreements between the defendant and its agents in South Carolina; evidently, the same patents were involved. The above history can be distilled from the following cases: Duplan Corp. v. Moulinage et Retorderie de Chavanoz, 487 F.2d 480 (4th Cir. 1973); Duplan Corp. v. Deering Milliken, Inc., 61 F.R.D. 127 (D.S.C. 1973); Duplan Corp. v. Deering Milliken, Inc., 353 F. Supp. 826 (D.S.C. 1973); Duplan Corp. v. Deering Milliken, Inc., 334 F. Supp. 703 (D.S.C. 1971).

It is clear that Chavanoz at least had an argument that the litigation from which work product was sought to be discovered met the "closely related" test. See Duplan Corp. v. Deering Milliken, Inc., 61 F.R.D. 127, 132-33 (D.S.C. 1973). Since neither the district nor the appellate court ruled on this issue, future litigants may attempt to avoid the Duplan rule by arguing that the case's result (though not its holding) could have been reached under the less expansive "closely related" rule. See notes 79-86 supra and accompanying text. 
under Rule $26(b)(3), \ldots$ and become freely discoverable in subsequent and unrelated litigation. ${ }^{89}$

After noting the general confusion regarding the Hickman doctrine, the court set out its own view of the justification for work product protection. Utilizing several quotations from Hickman, the Fourth Circuit strongly emphasized the importance of a lawyer's privacy: "[T]he thrust of the [Hickman] decision was the qualified protection of the the ... confidentiality and activity of an attorney which transcends the rights of the litigants." Ad Admittedly aware of "divergent conclusions reached in similar cases," the court simply maintained that these cases had "misread the basic teaching of Hickman." In particular, the court noted that soine courts did apply the "closely related" test, but the court felt that "to dispose of this delicate and important question by such a technical touchstone is incompatible with the essential basis of the Hickman decision."92 Therefore, the court reversed the district court" and held that the "qualified immunity of work product materials"94 was to be recognized in all subsequent litigation.

The Duplan decision is important for several reasons. First, it is the most recent federal case dealing with the problem of discovery of a lawyer's work product in subsequent litigation. Second, it is one of the few cases that have reached the courts of appeals on this issue. ${ }^{95}$

89. 487 F.2d at 481.

90. Id. at 483 .

91. Id. at 484 .

92. Id. at $484 \mathrm{n} .15$.

93. The district court had applied the Hanover-Honeywell rule which it found to represent the clear weight of authority:

(1) [W] hen a case in litigation is finally terminated; (2) by either a decision of the court or by settlement among the parties; (3) the work product privilege is also terminated; and (4) the work product of attorneys in the prior litigation is therefore subject to discovery in subsequent litigation. Duplan Corp. v. Deering Milliken, Inc., 61 F.R.D. 127, 135 (D.S.C. 1973).

94. 487 F.2d at 484.

95. Duplan is only the second case dealing with the issue to reach a federal appellate court. The other case, Republic Gear Co. v. Borg-Warner Corp., 381 F.2d 551 (2d Cir. 1967), is discussed in note 85 supra.

Few discovery cases reach the courts of appeals because interlocutory orders are not appealable under the final order doctrine. See generally Note, Discovery: Work Product and Good Cause Development since "Hickman v. Taylor," 36 IND. L.J. 186, 201 (1960). An appeal was possible in Hickman only because counsel refused to obey the district court's order for production and was cited for criminal contempt, which is an appealable final order. Congress subsequently passed the Interlocutory Appeals Act of 1958 which gives the appellate court discretion to review an interlocutory order when a district judge

shall be of the opinion that such order involves a controlling question of law as to which there is a substantial ground for difference of opinion and that an innnediate appeal from the order may materially advance the ultimate termination of the litigation . . . . 28 U.S.C. $\$ 1292(\mathrm{~b})(1970)$. 
Finally, it is also one of only a few opinions which undertake any significant analysis of the Hickman rationale. ${ }^{90}$ The Duplan court's analysis produced a somewhat unusual view of the work product doctrine, ${ }^{97}$ in which the purpose of the doctrine is to protect something inherently sacred in the lawyer's preparatory materials, rather than to prevent the potentially injurious consequences flowing from the attorney's anticipation of unlimited discovery. While some of the language used by Justice Murphy arguably supports such an interpretation of the rationale underlying the work product doctrine, ${ }^{08}$ this approach misreads the basic teaching of Hickman. For if it is assumed that attorney privacy is the foundation of the doctrine, the next logical question must be why it is especially important to protect an attorney's privacy. The answer, of course, is that protection is necessary to avoid the consequences which the Supreme Court presumed would follow from the lawyer's anticipation of unrestricted discovery. ${ }^{90}$ The Duplan case goes far beyond what is necessary to obviate the feared ill effects, for it would provide protection to material which was prepared by an

Duplan reached the appellate level because the district judge certified his order for interlocutory consideration pursuant to this provision and the Fourth Circuit granted the appeal. 487 F.2d at 481 .

96. The district court in Duplan devoted considerable space to the subsequent litigation issue, but its analysis was based primarily on the available precedent, rather than on the rationale underlying Hickman. See 61 F.R.D. at 130-35.

97. There is, however, one earlier ease with a holding similar to Duplan, LaRocca v. State Farm Mut. Auto. Ins. Co., 47 F.R.D. 278 (W.D. Pa. 1969). LaRocca involved a suit by a tortfeasor against his insurer to recover damages resulting from failure to settle the claim against him within the limits of his policy. LaRocca suecessfully sought discovery of correspondence between the insurer and its attorney. See note 73 supra. He also sought discovery of the file of the attorney of the plaintiff in the earlier case. In a supplemental opinion, discovery of this file was denied apparently on reasoning similar to that of Duplan. Id. at 281-82.

This latter holding of LaRocca seems to have been overlooked by the Duplan court since LaRocca is cited as having a "divergent conclusion." 487 F.2d at 484 \& n.15. That description could only apply to the successful discovery of insurer-attorney correspondence.

98. "It is not without reason that various safeguards have been established to preclude unwarranted excursions into the privacy of a man's work." 329 U.S. at 497. "Here is simply an attempt, without purported necessity or justification, to secure written statements, private memoranda and personal recollections prepared or formed by an adverse party's counsel in the course of his legal duties." Id. at 510. "II]t is es* sential that a lawyer work with a certain degree of privacy . ..." Id.

99. See notes $32,42-43,46$ supra and accompanying text. A passage later in the opinion gives an indieation that privacy itself is not the primary consideration. In concluding that petitioner's counsel had not shown "good cause," the Court said, "That is insufficient under the circumstances to permit him an exception to the policy underlying the privacy of Fortenbaugh's professional aetivities." 329 U.S. at 513 (emphasis added). The "policy underlying" the need to protect attorney privacy is the prevention of injuries to the adversary system. 
attorney without any fear that it might be the object of discovery in a later case. While the Duplan approach would certainly provide protection when it is required, it must be rejected because the policy of free discovery demands that work product protection be limited as much as possible. ${ }^{100}$

What influence Duplan will have on other courts is yet to be determined. ${ }^{101}$ Perhaps the more interesting and more important inquiry is what effect Duplan will have on the answers to other questions about the work product privilege. An adoption of the interpretation of Hickman espoused in Duplan could mark a "step backward to the antiquated and atavistic values of the common law,"102 unduly circumscribing the policy of liberal discovery embodied in the Federal Rules.

\section{A Proposed Test}

Having examined the Hickman rationale and its application by the courts to cases involving the discovery of work product in subsequent litigation, it is now appropriate to propose a test for deciding whether to afford protection in such cases, one that is lopefully more consistent with that rationale than those the courts have thus far developed. Since the rationale is prospective in nature-it focuses on the attorney's expectations at the time of the initial litigation-it should be possible to formulate an objective test which maximizes the importance of the predictability of subsequent litigation as the major element of that test. ${ }^{103}$

The first approach adopted by the courts, ${ }^{104}$ allowing discovery in all subsequent litigation, though certainly predictable, is unsatisfactory because it does not purport to protect against the evils envisioned by Hickman. The second approach, ${ }^{105}$ the "closely related" test, is deficient in predictablity because it is an after-the-fact test. It

100. See Note, supra note 85 , at 274.

101. Even if it is assumed that the Duplan decision is wrong, it may have salutary effects if it induces the courts to give more thought to the applicability of the Hickman rationale to the problem of discovery of work product in subsequent litigation.

102. LaFrance, supra note 14 , at 371 . This statement was made in the context of a discussion critical of the Hickman doctrine, but since Duplan is an arguably unwarranted extension of Hickman, see notes 97-100 supra and accompanying text, the criticism is equally applicable to Duplan.

103. See notes 82-83 supra and accompanying text. If the attorney anticipates future litigation and future discovery, unwanted consequences will presumably ensue. If it is desired to prevent these consequences, it would be necessary for the attorney to be able to determine, with reasonable certainty, that discovery would not be allowed in a foreseeable future case.

104. See notes 74-78 supra and accompanying text.

105. See notes 79-86 supra and accompanying text. 
evaluates the relationship between the initial and subsequent litigation from a retrospective standpoint, rather than from the point of view of an attorney involved in the earlier suit who must decide whether his work product will be protected in the future. Furthermore, the "closely related" standard is both over-inclusive and under-inclusive with respect to those cases in which Hickman suggests that work product protection is warranted. Finally, the third approach, ${ }^{100}$ affording protection in all cases, nay be criticized because it seems based on a misinterpretation of the Hickman rationale, and, in many cases, protects an attorney's work product from discovery when no protection is needed.

Accordingly, the best solution seems to be a "reasonable attorney" standard. The appropriate question would then be: Under the circumstances existing at the time of the preparation of the initial suit, would there have been in the mind of a reasonable attorney a belief that there was a substantial probability of significant subsequent litigation to which his present work product would be relevant? 107 $^{107}$ The merits of this test are apparent. First, this is a flexible rule in that it allows the trial judge to look at the circumstances of each case to determine whether the situation is one in which work product protection would be appropriate. In this respect, it is superior to both the HanoverHoneywell and Duplan approaches which lay down rigid rules. Further, the reasonable attorney standard is more faithful to the Hickman rationale than the other approaches. Like Hickman, ${ }^{108}$ it focuses on the attorney's expectations at the time of preparation. If the circumstances are such that a reasonable attorney would anticipate that his preparatory materials might be subject to discovery in the future, protection will be granted. ${ }^{100}$ Thus, the proposed test is solicitous of the need to maintain the efficacy of the adversary system. At the same time, it does not provide blanket protection, as does Duplan, which might undermine the free discovery policy of the Federal Rules.

However, there are two potential flaws in the reasonable attorney

106. See notes 87-102 supra and accompanying text.

107. Note that the test does not ask whether the reasonable attorney would alter his method of preparation. The test assumes, as does Hickman, that if the attorney anticipates discovery of his preparatory materials, undesirable consequences will occur. See note 46 supra and accompanying text.

108. See note 61 supra and accompanying text.

109. On the other hand, if the reasonable attorney would not have anticipated the possibility of future discovery, all protection would be refused, since there would be no reason for granting it, according to the rationale of Hickman. The result would be that rule 26(b)(3) would not apply at all, and even the attorney's mental impressions, conclusions, opinions, and legal theories would be subject to discovery. 
standard. First, the results which the test would yield in a given case might not be clearly predictable. ${ }^{110}$ An attorney who considers the problem must assess the situation and determine whether a reasonable attorney would anticipate subsequent litigation. A cautious attorney might "anticipate" subsequent litigation in nearly every case, and if he were unsure of the availability of protection in some instances because of the indefmiteness of the proposed standard, undesired consequences might ensue. Would not the predictable blanket protection of the Duplan rule then be preferable, even at the sacrifice of the policy objectives underlying liberal discovery provisions? The fact is that in most cases the attorney will not consider the potential for future discovery im a second suit, because the circumstances simply will not suggest the possibility of subsequent litigation. And if the problem does not occur to the attorney, the evils feared in Hickman will not result. Moreover, since those relatively infrequent instances where the attorney is concerned about subsequent litigation will be obvious from the factual context of the case, ${ }^{111}$ the attorney will usually be able to conclude that a reasonable attorney would also anticipate future litigation. Thus, the lack of predictability inherent in the reasonable attorney standard appears tolerable. ${ }^{112}$

A second problein with the reasonable attorney approach is that it may afford protection to some preparatory materials when no protection is necessary. Consider the case of the attorney who, applying the proposed objective test, erroneously believed that his work product

110. However, even the Duplan approach does not afford protection that is perfectly predictable; the possibility remains that the discovering party will be able to make the requisite "good cause" showing under rule $26(\mathrm{~b})(3)$ to override work product protection, and a lawyer might adjust his preparation because of this uncertainty.

111. The factual situation in Hanover Shoe, Inc. v. United Shoe Machinery Corp., 207 F. Supp. 407 (M.D. Pa. 1962), see note 74 supra, is an excellent example of circumstances suggesting subsequent litigation. Whenever the United States brings an antitrust action against a company, the defendant company's lawyers can very likely expect subsequent damage actions by the company's competitors if the government wins the suit.

From this example it may seem that the proposed test will afford work product protection in the later litigation only where the cases are "closely related." Generally this will be true. Consider again, however, the situation suggested in note 86 supra. And of course the reasonable attorney standard will allow discovery in situations where the "closely related" test may not. Consider the facts of Tobacco Allied Stocks, Inc. v. Transamerica Corp., 16 F.R.D. 534 (D. Del. 1954), discussed in note 76 supra.

112. The objection of unpredictability was previously raised as a fault of the "closely related" test. See notes 82-83 supra and accompanying text. The principal difficulty with that test is that its focal point-relatedness-is imperfectly related to the appropriate rationale for granting protection. The proper focus is on the issue of the attorney's anticipation of subsequent discovery. See notes 107-09 supra and accompanying text. 
would not receive future protection, yet did not allow that belief to affect his conduct. Why should this attorney's materials be protected when there was little danger that the evils sought to be avoided would occur? The short answer is that Hickman itself would protect that attorney's preparation materials in an analogous situation. ${ }^{113}$ Both Hickman and the reasonable attorney test presume that if the attorney fears discovery of his work product, undesired consequences will follow. ${ }^{114}$ There may be instances, however, where it can be "objectively" determined that a reasonable attorney, though he fully anticipated a subsequent suit, would not change his conduct in the first suit. This might be the case when the monetary or precedential importance of the first suit far overshadowed that of the contemplated second suit. Hence, the justification for including in the proposed test the requirement of anticipation of significant subsequent litigation. If the reasonable attorney would not, for some "objective" reason, attach significance to the anticipated subsequent suit, knowledge that his work product might later be discovered would not likely result in undesired consequences, and therefore his preparatory materials should not receive work product protection.

\section{Conclusion}

The test proposed here for determining when protection froin discovery should be afforded to an attorney's work product froin prior litigation can be easily integrated into the analytic framework suggested by the Hickman opinion. ${ }^{115}$ Recall that on one side of the balancing scales is the need to protect the adversary system from the injurious consequences which the Hickman Court assumed would result if an attorney anticipates free discovery of his work product. The Court in Hickman implicitly indulged the further assumption that an attorney would always anticipate the possibility of discovery of his work product in the suit for which it was prepared. This assumption is not relevant where the work product was prepared for a suit different from the one in which discovery is being sought. However, it seems fair to infer that a corollary of this proposition is that an attorney who antitcipates litigation will also anticipate discovery. The test proposed by this Note then asks if an attorney would have anticipated further related litigation, and thus discovery, at the time he

113. The "analogous situation" would occur if an attorney who knew that his preparatory materials would be discoverable in the case at hand did not allow the potential of discovery to affect his preparation.

114. See notes 46,107 supra and accompanying text.

115. See notes $40-45$ supra and accompanying text. 
prepared the work product in question. An affirmative answer to this inquiry is functionally equivalent to the Hickman Court's assumption that an attorney would expect discovery of his work product in the suit for which it was prepared. When coupled with the Court's finding that anticipation of discovery of work product leads to injury to the adversary system, the outcome of the proposed test determines the weight to be attached to the interest in affording work product protection, which must then be balanced against the interest in allowimg liberal discovery. The weight of this latter interest will vary with the need of the discovering party for the information, as revealed by the "good cause" showing that he inust make under rule 26(b) (3) when the interest in favor of work product protection is at stake.

Most importantly, the standard here proposed is concordant with the fundamental rationale and spirit of the Hickman case. By focusing on the attorney's expectations at the time of preparation for litigation, this standard recognizes the need of the adversary systen for counsel confident that the fruit of his labors will not be freely available to his opponent, while ensuring the freest possible interchange of information between litigants consistent with this objective, thereby engendering maximum progress toward what should be the ultimate goal of all courts in procedural decisions-effecting just and efficient resolution of disputes through the legal process. 